$\mathbf{M}$

Á

C

Így hivatkozzon erre a cikkre:

Székely Levente, Urbán Ágnes. „Digitális televíziós workshop az ESOF 2008 keretében”. Információs Társadalom VIII, 4. szám (2008): 132-135.

= https://dx.doi.org/10.22503/inftars.VIII.2008.4.15 ב

A folyóiratban közölt müvek a Creative Commons Nevezd meg! - Ne add el! - Így add tovább! 4.0 Nemzetközi Licenc feltételeinek megfelelöen használhatók. 
Székely Levente - Urbán Ágnes

\section{Digitális televíziós workshop az ESOF 2008 keretében}

Ez év júliusában Barcelona adott otthont a nagyszabású ESOF 2008 (The EuroScience Open Forum) találkozónak, ahol többek között a digitális televíziózásról is hallhattak az érdeklődók.

Az ESOF kétévente jelent találkozóhelyet Európa tudósai számára, akik számos tudományterületról verbuválódnak, hogy megosszák egymással kutatási eredményeiket, elősegítve ezzel az egyetemes és különösen az európai tudományos élet fejlődését. A cél valóban nemes, és a megvalósítás sem lebecsülendő, hiszen az idén július 18 . és 22. között megrendezett konferencián tengernyi programból választhattak a jelenlevók. Ezek egyike volt a COST 298 (Participation in the Broadband Society) páneurópai kutatási program által koordinált, digitális televíziózással foglalkozó workshop, amelyen Magyarország több résztvevővel is képviseltette magát. A COST (European Cooperation in the field of Scientific and Technical Research) különbözô tudományterületeken indít programokat, amelyek elsôsorban a kutatói hálózatok kiépülését, a tudás áramlását kívánják elốsegíteni, ezek sorában a négy éven át futó COST 298 program a széles sávú kommunikáció és az információs technológiák terjedésének trendjeit, következményeit vizsgálja.

A workshop célja az volt, hogy a digitális televíziózást több irányból, az üzleti szereplók, a fogyasztók és a közpolitika oldaláról vizsgálva áttekintést adjon a technológia terjedésének európai tapasztalatairól. A kezdő előadást a workshop vezetôjétól és szervezójétốl, a COST 298 program elnökétól, Bartolomeo Sapiótól hallhattuk, aki röviden bemutatta a program felépítését, vázolta a technológia, a felhasználók és a környezet viszonylatában felmerülő feladatokat, majd egy másik prezentáció keretében megadta az esemény alaphangját a digitális televíziózás rejtelmeibe bevezetố elôadásával.

Miben különbözik a digitális televíziózás a hagyományostól azonkívül, hogy a jel digitális formában érkezik a háztartásokba? (Az igazi digitális televízió persze az volna, ha nem lenne közbeiktatva az ún. set-top-box, amely az analóg tévék esetében a digitális jelek átalakításával teszi lehetôvé a vételt.) A felhasználó oldaláról közelítve a digitális technológia elsôsorban minőségben jelent látványos javulást az analóg megoldásokhoz képest (amit e sorok írója tapasztalatból nem tud megerősíteni). Több csatorna vételére nyílik lehetôség, gazdagabb audio- és videoszolgáltatások érhetốk el, és nem utolsósorban lehetôség adódik különféle interaktív szolgáltatások igénybevételére (pl. online bankolás, böngészés, vásárlás). A fogyasztói szokások átalakulását és új üzleti modellek megjelenését tekintve egyaránt új távlatokat nyithat, ha új alkalmazások jelennek meg egy televíziós platformon. Egy másik, szlovén és olasz kutatók közös projektjét összefoglaló előadásában, ami ugyanezen a wokshopon hangzott el késóbb, Sapio a digitális televíziózás kormányzati szolgáltatásaival (T-government) foglalkozott, felvil- 
lantva a közeljövốt, amikor kényelmesen, a karosszékból lehet majd ügyeket intézni sorban állás nélkül.

Urbán Ágnes, a Budapesti Corvinus Egyetem adjunktusa összefoglalta a digitális átállás eddigi európai tapasztalatait, kiemelve a technológiaváltásban élen járó országokban megfigyelhetố különbségeket. Azokat az országokat és digitális televíziózásuk múködési modelljét, ahol már lezajlott a digitális átállás, összehasonlította azokkal, ahol ez még folyamatban van, és rávilágított, hogy a múködóképes modellek önmagukban nem másolhatók, nincs „egyetlen legjobb út” (one bestway). Az átállás sikerét befolyásolják az ország jellemzôi, a televíziós piac felépítése és az átálláskor jellemzố technológiai adottságok. Néhány évvel ezelốtt például nem volt kérdés, hogy milyen tömörítési szabványt érdemes választani, a most átálló országokban azonban komoly dilemmát jelent a döntéshozók számára, hogy a régebbi, kiforrottabb MPEG-2 vagy az újabb MPEG-4 szabvány bevezetése mellett döntsenek-e. Az üzleti modellek országonként különbözók: míg például az Egyesült Királyságban csak ingyenes, Hollandiában csak fizetốs csomagokat kínálnak.

Habár a DTT (Digital Terrestrial Television) korszerú technológiának számít, máris számos kihívás éri például az IPTV (Internet Protocol Television) vagy a kábeles szolgáltatások oldaláról. A DTT egyik legjelentơsebb versenyhátránya, hogy nincs olyan exkluzív tartalom, amely csak ezen a platformon jelenne meg. Tovább gyengíti a DTT kilátásait, hogy az üzleti modellek sem egységesek. Ami mégis pozitívan befolyásolhatja a terjedését, az egyrészt a jelenleg még alig múködő interaktív szolgáltatásokban rejtôzhet, másrészt a nagyfelbontású televíziós képek sugárzása (High-Definition Television, $H D T V$ ) révén elérhetô minôségjavulás győzhet meg sokakat, hogy álljanak át a digitális televíziós szolgáltatásokra.

A magyar „kontingenst” erósítette a BME-ITTK két munkatársa, Csótó Mihály és Kollányi Bence, akik előadásukban a Magyarországon is hamarosan esedékes digitális átállás társadalmi vetületeivel foglalkoztak. Mondanivalójukat az innovációk terjedésére kidolgozott rogersi S-görbe elemzéséból kiindulva fejtették ki, amely a különféle infokommunikációs eszközök (pl. telefon, televízió, internet stb.) elterjedésének leírására is alkalmas, és lehetốséget ad a terjedési sebességek összehasonlítására. A problémákat az okozza, hogy az új eszközök egyre gyorsabban terjednek el, miközben nem biztos, hogy a társadalom egésze készen áll a fogadásukra, ráadásul a lemaradó csoportok nem jellemezhetók pusztán szociodemográfiai alapmutatókkal, lemaradásukban nagy szerepük van az attitúdöknek is. Ebból adódóan nehéz egyféle receptet kínálni, az egyes csoportokat különbözóképpen lehet és kell megszólítani.

A magyarországi helyzetet bemutatva a digitális tévé-és rádiómúsorok földfelszíni sugárzására kiírt tender kapcsán az előadók kitértek a politikai döntéshozók felelôsségére is. Mint ismeretes, a Magyar Országgyứlés ad hoc bizottsága az első körben érvénytelenítette a pályázat eredményét, a Nemzeti Hírközlési Hatóság megismételt pályázati értékelését azonban késóbb mégis elfogadta a politikai vezetés. Az előadás legfontosabb üzenete az volt, hogy az analóg adás beszüntetése igen heterogén társadalmi csoportokat érint, így nagy felelósség hárul a törvényhozásra, amelynek fontos szerepet kellene betöltenie a kifinomult információszolgáltatási lehetôségek megteremtésében.

Emiliano Trerè, az udinei egyetem PhD hallgatója az olaszországi egyetemi Net Tv-vel kapcsolatos tapasztalatokról számolt be. A gyorsan fejlődő technológiának kö- 
szönhetốen egyre újabb fogalmakkal találkozhatunk, fontos tehát megjegyezni, hogy a Net Tv nem azonos az IPTV-vel. Míg az utóbbi az internetes (IP-alapú) technológiával terjesztett televízióadás, addig a Net Tv horizontális kezdeményezés, amely a felhasználók részvételére és az általuk létrehozott tartalmakra épít.

Olaszországban 2003-ban kezdtek megalakulni az egyetemi Net Tv-állomások, és mára már szép számmal képviseltetik magukat (UniversyTV, AltraTV, Extracampus, uniMedia, UniversoTV, Webz.it, Campus Network). Helyzetüket és lehetséges jövójüket komplex, kvalitatív és kvantitatív eljárásokat ötvözó módszerrel vizsgálták, arra a kérdésre keresve a választ, hogy ezek a próbálkozások lehetnek-e olyan sikeresek, hogy országos méretúvé váljanak. A kutatás eredményei arra engednek következtetni, hogy amennyiben hálózatosodás révén sikerül úrrá lenniük a finanszírozási és szervezeti problémákon, ez a lehetôség fennáll, ellenkezô esetben azonban csupán laboratóriumi kísérletek maradnak.

Nyírô Nóra, a Budapesti Corvinus Egyetem PhD hallgatója az internethasználattal és a televíziónézéssel eltöltött idő kapcsolatát vizsgálta. Sokakat foglalkoztató kérdés, hogy az internetpenetráció növekedése vajon milyen hatással van a tévézésre, oka-e az internet megnövekedett szerepe a tévézéssel eltöltött idő csökkenésének? Vajon a nemzetközi tapasztalatokhoz hasonlóan megfelelóen Magyarországon is mind jobban elválik-e egymástól az „internetes” és a „televíziós” társadalom, kannibalizálja-e a televíziót az internet? Ezeket a kérdéseket a közönségek és a technológiák harcaként is fel lehet fogni, szembeállítva egymással az online és az offline közönséget, illetve a televíziót és az internetet.

Az előadó a közvetített tartalom alapján kétféle televíziózást és kétféle online fogyasztást különböztetett meg. A televízió megốrzi szerepét abban az esetben, ha a közönség erôs bevonódását biztosító és nagy képernyốt igénylő tartalmakról van szó (ilyenek például a filmek); ezt kiegészítheti az internet, ha valamilyen extra információra van szükség (például a futballmeccsek közvetítésekor); míg a párhuzamos fogyasztás esetén a televízió könnyen háttérbe szorulhat, és az online fogyasztás elótérbe kerülése mellett kialakulhat bizonyos háttértelevíziózás; végül a rövidebb videotartalmak esetében (például a filmelőzetesek megtekintésénél) egyértelmúen az online környezet válik uralkodóvá.

Hasonló témában hallgattuk meg az egyik leglátványosabb elốadást, amelyet Jakob Bjur (Göteborgi Egyetem, Svédország) prezentált a videotartalmak fogyasztásáról. Egy svédországi online kérdôíves vizsgálat eredményein mutatta be, hogy a videotartalmak fogyasztásának milyen technológiai és demográfiai jellegzetességei vannak. Az életkor az egyik meghatározó tényezố: az idôsebbek a televíziót részesítik elốnyben, míg a fiatalabbak jóval többször használnak internetes platformokat, és 20 százalékkal több videotartalmat fogyasztanak. Figyelemre méltó eredmény, hogy a 16-30 éves korosztályban az összes nézett videotartalomnak mindössze 66 százalékát teszi ki a televíziózás, a fennmaradó rész egyéb nézési formákhoz kötődik (pl. letöltés, letöltés nélküli streaming, videokazetta- vagy DVD-használat). A másik meghatározó változó a nemi hovatartozás: a férfiak inkább fogyasztanak videotartalmakat, mint a nók, és ezen belül is nagyobb a nem televíziós platformok (jellemzően az internet) használatának az aránya. Nem meglepő, hogy a hozzáférés is meghatározó tényezố: a gyorsabb internet a webes tartalmaknak, a gazdagabb csatornakínálat a televíziónak kedvez. 
Mindez azt jelenti, hogy a televíziózásra szánt idő csökken ugyan, de a videotartalmak fogyasztásával eltöltött idő összességében növekszik az internetes megoldásoknak köszönhetően. Az internet szerepét jól mutatja, hogy a 16-25 évesek egyharmad része az internetról letöltve nézte meg „A szökés” (Prison break) címú sorozatot, és jelentôs közönsége van a televízióban még nem, de az interneten már hozzáférhetô más sorozatoknak is - ilyen például a „Hősök” (Heroes) címú sorozat.

Sebastian Egger (Telekommunikációs Kutatóközpont, Bécs) az interaktív mobiltelevíziózás témakörében mutatott be egy érdekes kísérletet. Ennek során a társas interakciót vizsgálták egy speciális készülékkel, amely 32 felhasználó számára tette lehetóvé a mobiltelefonon való tévézést úgy, hogy eközben egymással különbözô módokon (hang, text, videó) tarthatták a kapcsolatot.

A mobiltelevíziós tartalmakat a kísérlet résztvevői sokkal szórakoztatóbbnak találták úgy, hogy közben élményeiket megoszthatták egymással. Ugyanakkor beszámoltak nehézségekról is: a mobilkészülékek - jórészt a kijelzố mérete miatt - nem tették lehetôvé az igazán kényelmes tévézést és ezzel párhuzamosan a textalapú csevegést is. Másrészt nem mindenkinek vált be az effajta többcsatornás kommunikáció és médiafogyasztás (multitasking), nehéz volt koncentrálni, a figyelmet megosztani.

A kiemelt előadásokon kívül még számos más érdekességgel is megismerkedhettek a workshop résztvevôi. Nicoletta Vittadini, az OssCom Média- és Kommunikációkutató Központ kutatója például egy kvalitatív kutatás eredményeiról számolt be, és bemutatta az olaszországi tapasztalatokat a digitális televíziózás területén. Katia Mihailova Szófiából (University of National and World Economy) a közszolgálati televíziózást érő kihívásokat elemezte, különös tekintettel arra, hogy miként tudják megtartani közönségüket a közszolgálati músorszolgáltatók. Ciprusi előadók a digitális televíziós technikának a diszlexia sikeres kezelésére való alkalmazását mutatták be.

Összességében egy jól sikerült, bár túlságosan is feszített programú workshopon vehettünk részt, ahol az összefoglaló előadásokon kívül színes egyedi kísérletekrôl is hallhattunk. Az előadások kifejezetten hasznosnak bizonyultak a témában kevesebb tapasztalattal rendelkezók számára is, és az előadások után kialakult kötetlen szekcióbeszélgetések során is számos érdekes gondolat került felszínre.

Annyi biztos, hogy az Európai Unióban hamarosan le fogják kapcsolni az analóg sugárzás képzeletbeli fókapcsolóját. Az eddigi tapasztalatokból látszik, hogy többféle úton is el lehet indulni, ami nem feltétlenül erôsíti a DTT esélyeit a többi versengő technológia mellett. Az elôadásokból és a szakmai beszélgetésekból kiderült, hogy a terület szakértối meglehetôsen szkeptikusak a DTT jövôjét illetốen, hiszen nincsenek számottevő technológiai elốnyei a többihez (például az IPTV-hez vagy a kábeltelevízióhoz) képest, és tartalmi vonatkozásban sem tud sok újat kínálni.

\section{Kapcsolódó linkek:}

Az ESOF2008 weblapja: http://www.esof2008.org/

A COST weblapja: http://www.cost.esf.org/ 